\title{
Pentingnya Pemahaman Terhadap Personil Oleh Pimpinan
}

Oleh :

Sonia Martini (17002155)

Email : sniamrtn@gmail.com

Jurusan Administrasi Pendidikan

Fakultas ilmu pendidikan

\begin{abstract}
Abstrak
Tujuan penulisan artikel ini untuk mengetahui pentingnya memahami personil dalam organisasi. Personil memegang peran yang penting dalam pelaksanaan proses manajemen, kunci keberhasilan manajemen terletak pada kemampuan manajer mendayagunakan para personil. Dengan cara menggerakan orang orang yang dipimpinnya, maka orang orang itu akan berbuat dan bertindak sesuai dengan arahan dan tujuan yang hendak dicapai. Disisi lain tidak jarang terjadi para personil tersebut mengalami hambatan atau gangguan, yang pada gilirannya perlu diberikan bimbingan dan pembinaan, sehingga yang bersangkutan dapat mengatasi masalahnya sendiri, dengan demikian para personil dapat menjalankan tugas tugas nya sesuai dengan keinginan pimpinan dan sesuai dengan tujuan orgnisasi dengan baik.

Kata kunci : personil, pemimpin.
\end{abstract}

\section{Pendahuluan}

Di era globalisasi saat ini persaingan dan kebutuhan setiap organisasi semakin meningkat,jadi untuk itu organisasi perlu memiliki karyawan yang berkualitas demi tercapainya tujuan organisasi, untuk itu pimpinan perlu memahami tiap tiap personil karna setiap individu memiliki perbedaan, baik dalam watak,sikap, serta perilaku. Organisasi 
merupakan suatu jembatan dalam membentuk suatu komponen yang dapat dijadikan oleh anggota untuk memecahkan suatu masalah. Dalam organisasi terdapat pemanfaatan kapasitas mental dari semua anggotanya guna menciptakan sejenis proses yang akan menyempurnakan itu ,dan juga dalam organisasi terdapat proses manajemen yang harus dijalankan oleh tiap tiap personil untuk mencapai tujuan organisasi.

\section{Pembahasan}

Pada suatu organisasi terdapat komponen komponen yang saling berkaitan satu sama lain dalam mencapai suatu tujuan, komponen utama nya yaitu pemimpin dan karyawan. Pemimpin perlu mengenal dan memahami para personil yang dipimpinnya, maka dari itu pemimpin harus memliki pengetahuan dibidang psikologi manajmen, karena psikologi manajemen mempelajari tingkah laku manusia di dalam manajemen.

Kunci keberhasilan manajemen terdapat pada kemampuan pimpinan mendayagunakan personil tersebut untuk mencapai tujuan manajemen. Pimpinan memiliki tanggung jawab yang besar dalam melakukan pembinaan kepada pegawainya.Pembinaan yang diberikan oleh pimpinan dapat berupa bimbingan maupun pengarahan. Imron (2012) mengatakan bahwa pembinaan yang diberikan kepada pegawai dapat dilakukan melalui bimbingan dan pengarahan (Ermita, 2019).. Personil merupakan individu yang harus memilki keterampilan keterempailan khusus agar dia dapat bekerja dan melaksankan tugas tugas yang sesuai dengan bidangnya di dalam pekerjaan. Produktivitas suatu organisasi bergantung dan ditentukan oleh derajat keterampilan yang dimilki oleh para personil yang terlibat dalam organisasi itu, tiap personil berperan sebagai alat untuk melaksanakan mekanisme manajemen, seperti halnya mesin dan instrumen teknik lainnya. Potensi utama yang harus dimilki personil adalah kecerdasan, sehingga mampu berpikir dan memecahkan berbagai masalah dan mengambil kebijakan dengan tepat.

Ada beberapa aspek diri personil yang perlu dipahami oleh pimpinan organisasi : (Hamalik, 1993)

1) Latar belakang sosial 
Keadaan sosial ekonomi dan sosial budaya masyarakat dimana seseorang bertempat tinggal sangat mempengarui terhadap sikap dan perilakunya. Pengaruh tersebut menyebabkan perbedaan sikap mengenai agama, politik, dan kelompok masyarakat lainnya.

2) Latar belakang keluarga

Aspek ini perlu dipahami dan dikenali, karena sering situasi dalam kehidupan keluarga, baik masa lampau maupun yang ada sekarang, besar pengaruhnya terhadap emosi, tingkah laku sosial, minat dan sikap, disipin seseorang.

3) Tingkat kecerdasan dan intelegensi

Kecerdasan bertalian dengan kemampuan bekerja dengan huruf huruf, angka angka pemecahan masalah berpikir logis, menyusun rencana dan sebagainya.

4) Tingkat pendidikan

Aspek ini perlu dikenali dan dipahami oleh pemimpin, karena tingkat pendidikan memberikan petunjuk tentang kemauan personil melakukan pekerjaan.

5) Keadaan kesehatan

Keadaan kesehatan personil perlu diperhatikan, karena merupakan unsur penting dalam pelaksanan perkerjaannya. Keadaan kesehatan meliputi kesehatan jasmani, rohani, dan kesehatan sosial serta sikap hidup sehat.

6) Sifat sifat kepribadian

Pemimpin perlu mengenal sifat sifat kepribadian staf dan bawahannya supaya lebih mudah melakukan pendekatan pribadi.

Adapun tujuan seorang pemimpin memahami personil :

a) Agar pemimpin dapat memberikan penugasan yang teapat sesuai dengan kemampuannya, sehingga diharapkan personil bersangkutan dapat melaksankan perkerjaan secara tepat, cermat, dan berhasil.

b) Mempermudah pemimpin mempertimbangkan cara menyampaikan instruksi penugasan dan kontrol berkomunikasi dengan bawahannya.

c) Pengenalan dan pemahaman terhadap personil membantu pemimpin dalam upaya memberikan bimbingan, mendiagnosa, kesulitanya, memecahkan 
masalah yang dihadapinya, sehingga pekerjaanya lebih berhasil dan menguntungkan organisasi.

d) Pemimpin juga bertanggung jawab dan wajib membantu perkembagan dan kemajuan personil bawahanya melalui kegiatan pembinaan personil.

e) Pengenalan dan pemahaman terhadap individu personil juga erat kaitannya dengan penilaian personil dan pengawasan ketenagaan.

Metode pengenalan dan pemahaman personil :

a. Catatan kumulatif

Catatan kumulatif adalah kumpulan catatan tentang jati diri masing masing personil yang diperoleh melalui pengamatan terus menerus, lengkap, asli, dan akurat. Catatan ini umumnya berisi keterangan tentang:

a) Latar belakang masyarakat

b) Latar belakang keluarga

c) Hasil belajar atau pelatihan

d) Hasil seleksi masuk calon pegawai

e) Skor jtes kecerdasan

f) Hasil pemeriksaan kesehatan badan

g) Catatan kehadiran kerja

h) Hasil percakapan wawancara

i) Catatan kegiatan berbagai forum pertemuan

j) Hasil hasil pekerjaan

k) Hasil sosiometri

1) Catatan tentang kegiatan kegiatan ekstra

m) Minat minat khusus

b. percakapan dan wawancara informal pimpinan dan staf personil dapat mengadakan percakapan infromal waktu waktu tertentu, misalnya sebelum masuk kerja, waktu istirahat, sebelum dan sesudah rapat rapat dan waktu waktu lainnya. Untuk kegiatan ini perlu 
diciptkan suasana bebas, akrab, dan saling mempercayai supaya peroleh informasi yang benar dan akurat.

c. Pengamatan ( observasi )

Pimpinan dapat melakukan pengamatan terhadap tingkah laku bawahannya pada setiap kesempatan yang ada setiap hari kerja. Dengan pengamatan ini, pimpinan dapat mengetahui kemampuan kerja, sikap, peran serta, hubungan antara personil, keterampilan psikomotorik dan sosial.

d. Angket

Angket terdiri dari sejumlah pertanyaan tertulis yang tersampaikan kepada personil (sebagai responden) untuk memperoleh jawaban secara tertulis. Di dalam angket dapat diajukan pertanyaan pertanyaan berbagai hal yang berkenaan dengan minat, motivasi, aspirasi, dan ambisi, kebutuhan dan kesulitan yang dialami oleh personil.

Setelah menjalankan metode pengenalan personil, pemimpin juga perlu melakukan cara-cara untuk meningkatkan kualitas kinerja karyawan, seperti :

\section{Memberikan motivasi}

Motivasi kerja adalah suatu perubahan energi dalam diri seseorang yang ditandai dengan timbulnya perasaan dan reaksi untuk mencapai tujuan. Motivasi mempunyai memiliki dua kompone, yaitu komponen luar dan dalam.

Motivasi berfungsi sebagai pendorong suatau perbuatan mengarahkan, menggerakan dan pembinaan tindakan individu dalam pekerjaannya. Motivasi terdiri dari dua jenis, yaitu :

a) Motivasi intrinsik

Motivasi intrinsik adalah motivasi yang mencakup di dalam situasi kerja dan memahami kebutuhan dan tujuan-tujuan staf. Motivasi ini sering juga disebut motivasi murni, yakni motivasi yang timbul dalam diri sendiri.

b) Motivasi ekstrinsik 
Motivasi ekstrinsik adalah motivasi yang disebabkan oleh faktor-faktor dari luar.

\section{Memperhatikan kebutuhan karyawan}

Karyawan tidak hanya ingin gaji dan benefit yang memuaskan, mereka juga ingin di hargai atas pekerjaan yang mereka lakukan, diperlakukan adil, memegang tanggung jawab, memiliki kesempatan untuk berkembang dalam karirnya, dan kesempatan untuk terlibat secara lebih signifikan dalam sebuah perusahaan. Pengakuan dan penghargaan yang diberi oleh seorang pemimpin kepada karyawan memerankan peran penting dalam unit kerja untuk mempertahankan karyawan. Dengan adanya penghargaan dan pengakuan, mereka merasa bahwa kontribusi mereka dihargai dan kualitas diri mereka diakui.

3. Melakukan komunikasi yang baik dengan karyawan.

Komunikasi merupakan kunci utama seorang pemimpin untuk dapat mengenal dan memahami bawahannya, dengan adanya komunikasi seorang pemimpin dapat mengamati secara lansung bagaimana keadaan bawahannya, untuk selanjutnya dapat diambil tindakan dan keputusan yang disesuaikan dengan keadaan karyawannya agar para karyawan tersebut dapat bekerja dengan nyaman sehingga hal tersebut akan berpengaruh terhadap kinerja mereka.

\section{Penutup}

\section{A. Kesimpulan}

Memahami personil sangat penting dan sangat berpengaruh terhadap kemajuan dan pencapaian tujuan organisasi, pemimpin perlu mengetahui watak watak dan kemampuan yang dimilki bawahanya, karena dengan demikian pemimpin lebih mudah dalam memberikan tugas yang sesuai dengan kemampuan yang dimiliki bawahannya, dan dengan 
pahamnya pemimpin dengan watak bawahannya pemimpin lebih mudah mengontrol pekerjaan bawahannya.

\section{B. Saran}

Demikianlah artikel ini saya buat, penulisan artikel ini masih jauh dari kata sempurna, untuk itu apabila ada kritik dan saran yang membangun untuk kemajuan artikel ini, penulis menerima dengan lapang hati, dan apabila ada kesalahan dalam penulisan artikel ini mohon dimaafkan. 


\section{Daftar Pustaka}

Ermita, M. R. (2019). Pembinaan Kinerja Pegawai Oleh Pimpinan Atasan Langsung Di Kantor Kementerian Agama Kota Bukittinggi. Jurnal Bahana Manjemen Pendidikan, 278-285.

Hamalik, O. (1993). Psikologi Manajemen Penuntun Bagi Pemimpin. Bandung: Trigenda Karya.

Prof. Dr. Wibowo, SE.,M.Phil. , 2007. Manajemen Kinerja, Jakarta : PT. Raja Grafindo Persada.

Wijayanti, Choirunnisa. 2013. Komunikasi dalam Manajemen.

Nugroho, Rakhmat. 2006. Analisis Faktor-faktor yang Mempengaruhi Kinerja Karyawan. 